\title{
Does Sharia Act as both a Mediator and Moderator in Salafi Radicalism?
}

Moorthy S. Muthuswamy

\begin{abstract}
Salafi (Islamist) extremism, embraced by organizations such as the Islamic State, is a global religion-invoking phenomenon whose primary cause is not clearly elucidated in the literature. Unlike most existing models or explanations of terrorism that attempt to explain stages or factors associated with the radicalization of individuals, this study aims to identify the dominant causal pathway behind the onset of Salafi extremism. The independent, dependent, and the variable associated with the causal pathway invoked here are public support levels for religious leaders as religious judges, the radical agenda they espouse, and the idea of Sharia as the law of the land, respectively. A linear regression analysis of the observational data from 20 nations reveals that the Sharia platform acts as both a causal mediator and moderator vis-à-vis the independent and dependent variables. This study suggests that the use of Kosovo as the control minimizes or eliminates confounding bias, and the high magnitude of computed coefficients of determination minimizes the contribution of any omitted variable. Thus, the preliminary conclusion is that the belief in Sharia as the law of the land, as advocated by religious leaders, provides the basis for radicalization and the emergence of Salafi jihadist groups.
\end{abstract}

Keywords: mediator; moderator; extremism; Sharia; Salafism; radicalism

\section{Introduction}

Salafi extremism is a religion-invoking ideology that has been embraced by terrorist entities, including the Islamic State, al-Qaeda, the Taliban, and Boko Haram. ${ }^{1}$ In discussing the rise of Salafi jihadist groups in civil wars in the Muslim world, Barbara Walter admits that the "growth [of the groups] suggests an underlying level of support from Muslim communities around the world that we do not yet understand." 2 Moreover, according to Omer Taspinar, there exists no consensus on terrorism's dominant primary cause —only the perception that the "root causes of terrorism and violent radicalism are extremely complex, multifaceted, and often intertwined. They resist simplification and easy categorization."”

This characterization of terrorism, with its insistence on irreducible complexity, makes coherent policy formulations inherently problematic. The identification of an associated causal pathway, as defined by a simple theory, is a possible way out of this conundrum, as John Mearsheimer and Stephen Walt explain, without elaborating how one might propose such a theory:

We need theories to identify the causal mechanisms [or causal pathways] that explain recurring behavior and how they relate to each other. Scholars should test hypotheses, of course, but in ways that are guided by a well-specified theory. 
Furthermore, theories are essential for defining key concepts, operationalizing them, and constructing suitable data sets. ${ }^{4}$

This paper posits a novel, well-specified theory of Salafi extremism that incorporates Sharia as part of a causal mechanism. I start by distinguishing radicalism from extremism and terrorism. Later, I define the ideology of Salafi extremism and connect its emergence with the worldwide propagation of a movement in Islam called Wahhabism, which originated in Saudi Arabia. Toward the end of the Introduction, I discuss the shortcomings of existing models and explanations and note the importance of the religion-based primary cause in enabling Salafi extremism. In the Materials and Methods section, I invoke the conceptual framework of a theme and its enablers as the basis for the proposed theory, define it, and discuss the associated data selection along with the independent and dependent variables. The Results section explores how the phenomenon grew in popularity to identify Sharia as the theme and religious leaders as its enablers. I use several existing surveys to conduct a linear regression analysis that supports this theory. In the Discussion section, I explore the implications of other causal pathways and confounding variables in the context of Kosovo as the control, that of this article vis-à-vis past scholarships, and the limitations of the proposed theory. I conclude that the empirical basis supports the role of Sharia as both a mediator and moderator, discuss deradicalization and counterterrorism policy implications, and make suggestions on how to recast such policies.

\section{Radicalism, Terrorism, and Salafi Extremism}

While the words "radicalism" or "extremism" are arguably subjective, in this paper, I adhere to the following interpretation proposed by Alex Schmid in distinguishing radicalism from extremism: "While both stand at some distance from mainstream political thinking, the first tends to be open-minded, while the second manifests a closed mind and a distinct willingness to use violence against civilians." ${ }^{5}$ In this context, a radicalized person may be peaceful, but an extremist is one who seeks to impose his/her radical agenda through violence. A radical agenda is also a form of political aim. "Terrorism," too, remains a contested term. ${ }^{6}$ Bruce Hoffman defines terrorism as "violence - or equally important, the threat of violence — used and directed in pursuit of, or in service of, a political aim." "Similarly, Louise Richardson believes terrorism is "deliberately and violently targeting civilians for political purposes." 8

Salafism is a religious practice closely identified with Wahhabism (see below) that strives to return to Islam's earliest roots (salaf is Arabic for "ancient one). ${ }^{9}$ As noted by Bernard Haykel, only the minority has embraced Salafi extremism such as Salafi jihadism, with the Salafi majority consisting of those working within the system to advance political agendas or those who shun all forms of overt political action. ${ }^{10}$

The global Salafi jihadist movement based in the Sunni branch of Islam began to take shape only in the 1990s. ${ }^{11}$ According to the 2014 and 2018 RAND reports, in 1988, there were just three Salafi jihadist groups. However, by 2018, there were 67, spread across the planet. ${ }^{12}$ While there are variations in Salafi practices, Walter generally identified the ideology of Salafi extremists 
with an armed jihad (religious war), the rejection of democracy, and the embracing of a very narrow and conservative version of Sharia. ${ }^{13}$ Sharia is a religious leader's interpretation of Islam. ${ }^{14}$ That Salafi-based violence dominates all forms of terrorism is evidenced by the fact that $28 \%, 19 \%$, and $18 \%$ of all known terrorism-related fatalities in 2013 were due to the Taliban, the Islamic State, and Boko Haram, respectively. ${ }^{15}$ Moreover, of the top ten groups, the top eight Islamist militant groups — of which seven are affiliated with the Salafi group al-Qaeda - together generated $96.4 \%$ of all known fatalities. ${ }^{16}$

\section{Wahhabism's Worldwide Propagation and its Functioning Within Saudi Arabia}

When a new social phenomenon emerges, so do its backers/enablers. We can identify how it all started. It is now widely acknowledged that the emergence of Salafism coincided with the worldwide propagation of Wahhabism. ${ }^{17}$ However, the present article aims to explain for the first time how and why Wahhabism's propagation led to Salafism's emergence. Starting in the 1960s, a growing pan-Islamist social movement in Saudi Arabia set the stage for Wahhabism's worldwide propagation, which intensified in the 1980s. ${ }^{18}$ The March 1, 2002, edition of the Saudi government English weekly Ain Al-Yaqeen detailed Wahhabism's propagation:

The cost of King Fahd's efforts in this field has been astronomical, amounting to many billions of Saudi riyals. In terms of Islamic institutions, the result is some 210 Islamic centers wholly or partly financed by Saudi Arabia, more than 1,500 mosques, 202 colleges, and almost 2,000 schools for educating Muslim children in non-Islamic countries in Europe, North and South America, Australia, and Asia. ${ }^{19}$

The oil largesse seems to have ensured that Saudi Arabia did not have to reform its religious practices. ${ }^{20}$ Moreover, Saudi Arabia seems to have the pedigree vis-à-vis propagating Salafi extremism worldwide. According to Haykel,

Salafis are closely identified with the Wahhabis of Saudi Arabia because of a shared theological orientation. The Kingdom of Saudi Arabia adheres to a Salafi interpretation of Islam, and its promotion and defense have been a source of legitimacy for its ruling family since the mid-18th century. The development of a distinct Salafi political ideology has been in progress since the mid- $20^{\text {th }}$ century and has yet to coalesce into a dominant current. This began with the government of Saudi Arabia's promotion of Pan-Islamism ... while also funding institutions and programs that spread globally a Salafi interpretation of Islam. ${ }^{21}$

Saudi Arabia, as well as its citizenry, has a well-known record of sponsoring jihadist groups abroad. ${ }^{22}$ Moreover, textbooks sanctioned by the Saudi Arabian government have deemed armed jihad to be the "pinnacle of Islam." 23 According to a 2015 study, the kingdom was among the largest exporters of foreign fighters to the Islamic State. ${ }^{24}$ 
A prominent Saudi Arabian charity involved in spreading Wahhabism worldwide, the Muslim World League, defined its primary means to further the goal: "calling on individuals, communities, and state entities to abide by the rules of the Sharia (Islamic law)." ${ }^{25}$ The April 1980 declaration of its general secretary, Muhammad Ali Harakan, that "jihad is the key to Muslims' success and felicity" received significant coverage well beyond Saudi Arabia. ${ }^{26}$ Moreover, Saudi Arabian-trained religious leaders were at the forefront of propagating Wahhabism and its Sharia construct abroad. ${ }^{27}$

In the context of the proposed theory, it helps to understand Wahhabism's practices in Saudi Arabia itself, which is Islam's birthplace and home to its two holiest mosques. First, an exclusionary outlook characterizes Wahhabism. ${ }^{28}$ In the kingdom, Sharia is deemed an allencompassing "divine" law of the land (similar to the Salafi aspirations, see below) and is seen as an essential guide to life. ${ }^{29}$ It is pertinent to note the role of religious leaders (ulama) there:

The Islamic Sharia is the prevailing law in Saudi Arabia; the sacred law is the foundation of the legal system. As such, the Quran and the Sunna [sayings and actions of Muhammad] are the main sources of law. Judges and other legal scholars (ulama), as the lawful interpreters of the two holy sources, apply the Islamic Sharia in rendering a judgment or advice (fatwa) on individual cases brought before them. ${ }^{30}$

This strict law sanctions corporal punishments or religion-based radical agendas such as whippings or cutting off thieves' hands. ${ }^{31}$ Sharia is not merely a theme in Saudi Arabia, as it is the law of the land and religious leaders are its officially sanctioned enablers. Moreover, this self-serving Sharia construct endows religious leaders with immense religious and political influence and allows them to dictate Wahhabi practices there. The Sharia platform provides religious leaders with a powerful venue in which to advocate the radical agenda of armed jihad. For example, during the Soviet occupation of Afghanistan, the then-grand mufti of the grand mosque at Mecca, Ibn Baz, issued a fatwa that "the Afghan jihad is a legitimate jihad." 32 More recently, 52 Saudi Arabian religious leaders issued a fatwa to call on people to battle the Russian forces in Syria by waging an armed jihad. ${ }^{33}$ Hence, the proposed theory describes the dominant causal pathway of radicalization at play in Saudi Arabia.

A fatwa is a religious leader's legal opinion drawn from Sharia. Religious leaders issue fatwas in response to the public's questions in all manner of daily and public policy issues in Saudi Arabia and elsewhere:

In theory, the proliferation of fatwas is meant to provide greater clarity. Muslims can rely on their local mosque leader or other respected figures to interpret and adapt complicated 1,400-year-old religious texts in ways applicable to their modern lives. In practice, the result is often confusion, as men with the most tenuous religious training issue fatwas with impunity, and often with contradictory conclusions. ${ }^{34}$ 
The inherent deficiencies of taking what are mostly opinions and calling them divine law are elaborated in this example of a clerical ruling that advised the public to avoid a supermarket chain because it allowed female and male employees and customers to mingle. ${ }^{35}$ As a result, the chain was forced to shift some of its female employees. ${ }^{36}$ Although the Saudi king issued the following royal decree in 2010, Sharia not being codified in statutes and being interpreted by religious leaders has led to significant variations in its interpretations:

As part of our religious and national duty, we want you to ensure that fatwas are only issued by members of the Council of Senior Religious Scholars and other permitted people. Individual fatwas on personal matters such as matters of worship, dealings, personal matters are exempt from this ruling, but they should be between the questioner and the scholar. There should be a total ban on any topics involving strange or obsolete views. ${ }^{37}$

The preceding discussion in this section supports the premise that not only Saudi Arabia leveraged its prestige and resources to support religious leaders' propagation of Wahhabism, but that it has also been well-placed to advance the platform of Sharia law as the law of the land and that of religion-based radical agendas.

\section{Limitations of Existing Models and Identified Risk Factors of Terrorism}

How do some of the prominent models of terrorism explain why individuals embrace Salafi extremism? Michael King and Donald Taylor contended the following:

Considering the discrepancies and the commonalities among the five models, and the lack of empirical research verifying the factors and processes within these models, no one model can be distinguished as being more accurate than any other. This conclusion does not only apply to the models reviewed in this article, but can be generalized to most descriptions of radicalization in the broader field of terrorism studies. ${ }^{38}$

From the present article's perspective, the discrepancies between the models or among most of the descriptions of radicalization arise from varying local conditions ${ }^{39}$ that dictate stages or factors associated with the radicalization of individuals.

More generally, in a study of terrorism research published between 1990 and 2015, Sarah Desmarais et al. noted that only six articles presented statistical comparisons between a group of known terrorists and a group of non-terrorists. ${ }^{40}$ As a result, they concluded that the empirical evidence of risk factors that discriminate between terrorists and non-terrorists is limited. The six articles identified nine potential risk factors of individuals embracing terrorism - age, socioeconomic status, prior arrests, education, employment, relationship status, having a grievance, geographic locale, and type of geographic area. ${ }^{41}$ Desmarais et al. also listed the following factors as meriting further evaluation: at the individual level, country of birth, Islamic faith, military experience, foreign travel history, having family or friends in a terrorist or 
extremist organization, income inequality, or being influenced by the media or the government. ${ }^{42}$ However, the authors did not discuss how the aforementioned risk factors can be linked to a causal pathway behind Salafi extremism's onset.

However, these risk factors/drivers could not initiate religious radicalization by themselves. If they did, non-Muslim communities and even Muslim communities before Wahhabism's initial propagation in the 1980s (see above) would have had a similar experience. However, this is not the case. ${ }^{43}$ Hence, these risk factors are not the primary causes of religion-invoking extremism; only religion and its associated entities form the basis of the causal pathway(s) behind the onset of Salafi extremism. To keep the focus, I forego a detailed discussion of existing models or the impact of individuals' radicalization risk factors.

\section{Materials and Methods}

\section{Conceptualizing a Theory of Salafi Extremism}

Let us consider the impact of Wahhabism's worldwide propagation, as discussed previously. Unlike in Saudi Arabia, where Sharia is all-encompassing and strict, in most Muslim-majority nations - as a reflection of their embracing of modernity - Sharia law matters less, as it is applied mainly in the domestic sphere, to settle family or property disputes. ${ }^{44}$ Before Wahhabism's propagation outside of Saudi Arabia, radical Islamic leaders-including Hassan alBanna and Sayyid Qutb in Egypt and Abul Ala Maududi in Pakistan — had only limited success in popularizing the theme of Sharia as a "complete" divine guide to life. ${ }^{45}$ However, the emerging worldwide Wahhabi influence and the growing support for Sharia is evident from the 2007 World Public Opinion global survey conducted in Morocco, Egypt, Pakistan, and Indonesia. ${ }^{46}$ In this survey, a substantial majority supported the requirement of a "strict application of Sharia law in every Islamic country" and indicated a desire for a "caliphate" - a unified Islamic state governed by Sharia. ${ }^{47}$ In a 2012 Pew Research survey, 66\%, 75\%, 81\%, and $54 \%$ of those polled in Morocco, Egypt, Pakistan, and Indonesia, respectively, considered Sharia

to be the revealed "Word of God." of divine law_like the "holy land" of Saudi Arabia — can be appealing in its own right. The emerging worldwide influence of Wahhabism is sometimes referred to as "Arabization," often identified with women wearing a veil and men growing facial hair. ${ }^{49}$

The aspirations noted above have provided an impetus for the formation of homegrown jihadist groups and a recruitment basis for transnational ones. ${ }^{50}$ That is, a Salafi movement consisting of both nonviolent fundamentalists and jihadists was formed due to the public's shared belief that social problems could be overcome by strictly applying the "divine law" of Sharia both at the personal and societal levels (as the law of the land). In other words, the data outlined in the previous paragraph seem to suggest that this construct of Sharia defines a comprehensive religion-invoking ideology through a set of beliefs about the proper order of society and how it can be achieved, with religious leaders - the Sharia experts - guiding the flock. ${ }^{51}$ Indeed, this 
could be why the call to embrace Sharia has come in the name of a broad spectrum of religious leaders. ${ }^{52}$ For example, the declaration of a 2008 conference in India attended "by an estimated 10,000 Islamic clerics, scholars, muftis, and teachers of madrasas" from across the country called on Muslims "to spend their lives...following [the] Islamic Shariah and teachings with full confidence," 53 according to a 2011 news report, some 60 million Muslims worldwide watched a long-running weekly program titled ash-Shariah wal-Hayat ("Sharia and Life"), moderated by the Qatar-based cleric Yusuf al-Qaradawi on the Al-Jazeera television network. ${ }^{54}$

Although no direct evidence exists on the growth (over time) of the public support for Sharia as the law of the land and for some radicalization measures, it has been proposed that age-specific correlations $^{55}$ could be an alternative. In Britain, reports indicate that 100,000 impressionable Muslim children attend evening Islamic classes in the United Kingdom, often held in mosques, for up to two hours a day, and where they learn the basic tenets of Sharia and where the curriculum often criticizes Jews and Hindus. ${ }^{56}$ and that Wahhabis have co-opted many of these mosques. ${ }^{57}$ Indeed, it is hard to conceive how Muslim children could have learned the tenets of Sharia without exposure through religious education classes. The significance of this data is that while older Muslim adults tend to have a nuanced outlook toward religion and generally lack an intense exposure to Sharia and radical agendas through Wahhabi propaganda, many Muslim children in their formative years have been thus exposed. Accordingly, one would expect increased support for Sharia and some radicalization measures, with the youngest group supporting the most, thanks to its exposure to Wahhabi propaganda. Indeed, according to a 2007 British survey, among Muslim people aged 16-24 years, 37\% preferred Sharia over British law, $13 \%$ admired al-Qaeda, and 36\% supported killing apostates, whereas the results were 32\%, 6\%, and $37 \%$, respectively, among those aged 25-34 years, and 17\%, 3\%, and 19\%, respectively, among those aged 55 years and older. ${ }^{58}$

Moorthy Muthuswamy proposed a generalized framework to explain a social process by associating it with its enablers and the theme they promoted. He suggested that this framework could explain Salafi extremism. In this approach, the theme appeals to the masses, and its enablers have a self-interest in promoting it. ${ }^{59}$ Moreover, the platform provided by the associated theme's success gives the enablers an avenue through which to market their agendas of interest.

Accordingly, any robust framework of Salafi extremism needs to incorporate Saudi Arabia, religious leaders, and Sharia. I propose the following theory of Salafi extremism using the above framework, invoking only religion and its entities: backed by the prestige and resources of Saudi Arabia, religious leaders have popularized the appealing theme of Sharia as all-encompassing "divine law" to advance radical agendas that act as precursors to extremism. ${ }^{60}$

The causal pathway defined in the theory is as follows: Religious leaders have popularized the appealing theme of Sharia as all-encompassing "divine law" to advance radical agendas. The act of radical agendas as precursors to extremism is shown by process tracing. The theory's independent and dependent variables reflect the public support for religious leaders as religious judges and for the radical agenda(s) they espouse. As Sharia is a religious leader's interpretation 
of Islam, it is not considered an independent variable per se. Rather, the proposed Sharia platform (measured by the public support for Sharia as the law of the land) as the dominant causal pathway explains why religious leaders were influential in propagating radical agendas. In the proposed theory, Saudi Arabia, which derives its prestige as Islam's birthplace, is seen as a prominent backer of the Sharia construct through its propagation of Wahhabism and its training of religious leaders. However, it is not considered an independent variable because religious leaders espouse radical agendas, especially those invoking religion and popularizing Sharia.

The method used here is a covariation analysis that involves hypothesis testing. If a theory states that independent variable $A$ causes dependent variable $B$, and that there exists a variable $C$ that lies in the causal pathway between A and B, validating that causality involves establishing the following conditions: (1) determining whether A is causing B, and not the other way around; (2) determining whether A and B correlate; and (3) based on the strengths of the correlations between all the three variables and by utilizing a control to show that any omitted or confounding variables could make only minor contributions, respectively. ${ }^{61}$ Additionally, the premise of causality is established by showing that the Sharia platform defined by the variable $\mathrm{C}$ acts as a causal "mediator" between A (the influence of religious leaders) and B (the popularity of the radical agenda they espouse). ${ }^{62}$

A mediator's influence, over time, can evolve to become a "moderating" one, ${ }^{63}$ with the moderator dictating the strength of the relationship between A and B. ${ }^{64}$ The moderation effect signifies that the Sharia platform can also act independently of religious leaders' influence, ${ }^{65}$ and that as Sharia's popularity grows over time so do the influences of A and B. The linear regression analysis results are summarized in Tables 3-5 for the confidence interval of 95\%. As the residual errors associated with the figures are stochastic, the magnitudes of $\mathrm{R}^{2}$ are used to measure the goodness of fit. The P-value of less than 0.05 is used to invoke the statistical significance of the analysis.

While this study uses observational data of the affected populations, it uses Kosovo as the control. Although the data presented in Table 1 is cross-sectional, they constitute different time scales vis-à-vis local initiations of the underlying Wahhabi influence. For example, Eastern European nations with a strong secular history, such as Kosovo, were exposed to the Wahhabi influence much later than nations with higher support levels of Sharia, such as Pakistan.

\section{Data Selection}

The relevant qualitative and quantitative data that went into this scholarship were acquired from published scholarships, news reports, and analyses. Specifically, the primary statistical data utilized here were published by think tanks or dedicated polling forums such as the Pew Research Center, and as noted before, World Public Opinion. The Pew Research Center conducted public opinion surveys between 2008 and 2012 in 39 countries and territories in Africa, Asia, and Europe. ${ }^{66}$ Other than China, India, Saudi Arabia, and Syria, they covered every 
country with at least 10 million Muslims among their population. ${ }^{67}$ These data are aggregated in Table 1. Here, the religious leader-sanctioned radical agenda is the corporal punishment of cutting off the hands of thieves and robbers. ${ }^{68}$ The data represent communities that span economic, political, linguistic, and cultural faultlines, thus reducing selection bias. ${ }^{69}$ There is less than a $1 \%$ margin of error in collecting data with some (rather than all) of the Muslim population at the $95 \%$ confidence level. ${ }^{70}$ In Table 1 , column 10, the specified designations that reflect the strength of homegrown jihadist groups — no/weak/strong — represent Muthuswamy's work. ${ }^{71}$ The entire data was included in the linear regression analysis, as their representations in Figures 1, 2, and 3 do not suggest the need for any exclusion.

To establish Condition 1, I discuss the role of religious leaders in generating and propagating radical religion-invoking agendas and ideologies. To validate Condition 2, I provide a correlational analysis between the independent and dependent variables in approximately 20 nations. To validate Condition 3, I use a two-step process. First, I present data from Kosovo to argue that the country may be used as the control to establish the Wahhabi influence as the dominant source of Salafi radicalization worldwide, identify the Sharia platform as a causal pathway, and assist in process tracing. Second, in this context, by invoking a linear regression analysis of the variables in about 20 nations, I argue that the Sharia platform constitutes the dominant causal pathway. Finally, I provide a correlational analysis between the dependent variable and the homegrown jihadist groups' strength to explain that the extent of radicalism is an important precursor to violent extremism or terrorism in that community.

\section{Results}

\section{The Role of Religious Leaders in Enabling Violent Extremism}

It is pertinent to highlight the role of religious leaders as enablers of religion-invoking extremism. First, religious leaders stand out for their presumed exegetical expertise in religious ideologies, including religion-based agendas, and as the sole Sharia experts, owing to the definition of Sharia as a religious leader's interpretation of Islam. This result meets Condition 1 of the causality test. Second, religious leaders do espouse armed jihad, and they do so at many of the religious schools they run, ${ }^{72}$ and those who espouse it play a prominent role in online radicalization. ${ }^{73}$ Third, by analyzing the writings of religious leaders on the Internet, Richard Nielsen estimated that approximately $10 \%$ espouse this form of jihad. ${ }^{74}$ Fourth, radical religious leaders such as Abdullah Azzam, ${ }^{75}$ Mohammed Omar, ${ }^{76}$ Abu Bakr al-Baghdadi, ${ }^{77}$ and Mohammed Yusuf ${ }^{78}$ have either founded or led al-Qaeda, the Taliban, the Islamic State, and Boko Haram — all of which are Salafi jihadist groups.

\section{Validating the Dominant Causal Pathway of the Proposed Theory}

Wahhabi-Induced Transformation of Secular Kosovo

First, a historical context of Kosovo's Islamist evolution is in order: 
During the communist period, religious communities were under state control, and their impact on society was quite limited. With the beginning of transition and efforts for freedom of Kosovo, the political pluralism among ethnic Albanians was developed based on strong ethnic secularism with multi-religious cohabitation, which, as such, was coinciding with modern European values and aspirations. However, this secular social and political identity of Kosovo Albanians started to fade immediately after the war of 1999, with the intrusion of religion-based organizations from the Middle East countries. Moreover, after the Declaration of Independence in 2008, political and radical Islam started to grip the significant ground in Kosovo, which also coincided with the "Arab Spring" and the emergence of the "Islamic State of Iraq and Syria." 79

Supported by the following empirical data, one may view Kosovo as the "control" 80 in causally linking Wahhabism's worldwide propagation with the onset of Salafi radicalization, enabled by religious leaders. First, until 1999, Kosovo's political and social identity was secular, ${ }^{81}$ while in much of the world, Wahhabism's propagation had been underway for nearly two decades and was showing the telltale signs of its influence. ${ }^{82}$ For example, when about 4,000 jihadists from Peshawar, Pakistan, went to fight on behalf of the Kosovars in the early 1990s, not surprisingly, "the term [jihad] struck no chord in the local Muslim population." ${ }^{83}$ Second, beginning in 1999, Kosovo changed as well, with the intrusion of religion-based organizations from Middle Eastern countries (see above and below) ${ }^{84}$ These empirical data can be seen as proof that both around the world and post-1999 Kosovo, Salafi extremism's onset was predominantly brought about by Saudi Arabia's worldwide propagation of Wahhabism, not by any other influence. While Qatar, the United Arab Emirates, and Bahrain have also financed the spread of similar ideas and practices in Kosovo (and elsewhere) to a lesser extent, they, too, share Wahhabi ideology with Saudi Arabia ${ }^{85}$ Hence, the independent variable A, the dependent variable B of the hypothesis, and variable $\mathrm{C}$, constituting the dominant causal pathway, or any other omitted or confounding variables should be viewed only in the context of Wahhabism.

Indeed, a 2015 study by a think tank recognized "the strong impact of Saudi Arabia in introducing more conservative religious ideas and practices" in Kosovo, and that, among the nations that sent fighters to the Islamic State of Iraq and the Levant, Kosovo had the "highest number of foreign fighters per capita of their respective Muslim populations." ${ }^{186}$ In a 2016 report, journalist Carlotta Gall observed that through "the mid-2000s, Saudi money and Saudi-trained clerics were already exerting influence....and that the Saudi-trained imams propagated Wahhabism's tenets: the supremacy of Sharia law as well as ideas of violent jihad and takfirism, which authorizes the killing of Muslims considered heretics for not following its interpretation of Islam. ${ }^{" 87}$ A 2015 Kosovo government report asserted that religious leaders played a role in "encouraging" or "recruiting" for the Islamic State, and also "contributed to the development of a religious extremist ideology." 88 Advancing the cause of Sharia, too, has proven to be a valuable recruiting tool in Kosovo for the Islamic State. ${ }^{89}$ 
In Kosovo, via the statistics in Table 1, the data support the proposed causal pathway of radicalization - that religious leaders have popularized the appealing theme of Sharia as allencompassing "divine law" to advance radical agendas: compared to those who do not favor Sharia as the law of the land, those who do are nearly five times more likely to be supportive of religious leaders and their radical agendas. That is, variables A and B correlate (Condition 2), and that the impact of the Sharia platform is significant. Thus, in Kosovo, religious leaders managed to propagate radical agendas thanks to the Sharia platform in the context of Wahhabism's propagation. In Kosovo, the overall support for Sharia as the law of the land, for the role of religious leaders in politics, for religious leaders as religious judges, and for a radical agenda were only $20 \%, 27 \%, 10 \%$, and $10 \%$, respectively. It was much more difficult for a homegrown jihadist group to take root there (Table 1, Column 10). The next section empirically shows that Sharia constitutes the dominant causal pathway.

\section{Correlational Analysis of Religious Leaders' Leveraging of the Sharia Platform to Propagate} Radical Agendas

I computed the correlation coefficient for the data associated with independent (A) and dependent (B) variables in Table 1 (Columns 4 and 7) using a Microsoft Excel spreadsheet software; it is 0.91 , suggesting a strong positive correlation between these variables. ${ }^{90}$ Moreover, the coefficient of determination, $\mathrm{R}^{2}$ (Figure 1 ), with a value of 0.83 , when A was (linearly) regressed with $B\left(P-v a l u e<0.001\right.$ and $R^{2}=0.83$ ), indicates that $83 \%$ of the variation in the support levels of the radical agenda is due to the influence of religious leaders and that the results are statistically significant. It is pertinent to note that the average support levels for religious leaders as religious judges and their involvement in politics are comparable (Table 2). As described in the theory, these two tables outline how the independent and dependent variables correlate (Condition 2) through the causal pathway defined by Sharia's popularity.

Regarding the mediator analysis, the computed (unstandardized) path coefficients for $\mathrm{A}$ and $\mathrm{C}$ (Table 3, Row 6) were 0.32 and 0.46 , respectively, when $A$ and $C$ were regressed with $B$. Not surprisingly, these significant path coefficient magnitudes reveal that the mediation effect of the Sharia platform dominates over the direct effect of religious leaders influencing the public's support of radical agendas. The computed Sobel test ${ }^{91} \mathrm{P}$-value of 0.01 indicates that Sharia's (partial) mediating effect between the independent and dependent variables is statistically significant. I invoked the data from Table 1 - from Columns 4 and 7 - to compute moderated or interactive effects between $\mathrm{A}$ and $\mathrm{C}$ (the interactive variable is the product of the mean-centered values of $A$ and $\mathrm{C}^{92}$ ) when regressed with $\mathrm{B}$. Owing to the P-value of less than 0.05 and with an (unstandardized) path coefficient for the interaction term of 0.84 (Table 3, Row 7), the combined data show the moderation effect of the Sharia platform. Table 4 summarizes the linear regression analysis of the data corresponding to those who favored Sharia as the law of the land, where only the mediation effect of Sharia shows as being statistically significant. Whereas in Table 5, corresponding to those who do not favor Sharia as the law of the land, both the mediating and moderating effects of Sharia show as being statistically significant. 
However, the question is whether the Sharia platform constitutes the dominant causal pathway. The computed correlation coefficients of 0.92 and 0.93 suggest that the variables religious leaders (A - Column 4) and Sharia (C-Column 2) and Sharia $(\mathrm{C}$ - Column 2) and the radical agenda ( $\mathrm{B}$ - Column 7), respectively, are highly correlated. Moreover, the associated $\mathrm{R}^{2}$ values in Table 3, 85\% of the variation in $\mathrm{C}\left(\mathrm{P}\right.$-value $<0.001$ and $\left.\mathrm{R}^{2}=0.85\right)$ are due to the variations in $\mathrm{A}$, and $86 \%$ of the variation in $\mathrm{B}\left(\mathrm{P}\right.$-value $<0.001$ and $\left.\mathrm{R}^{2}=0.86\right)$ are due to the variations in $\mathrm{C}$, show both statistical significance and the role played by Sharia as a causal pathway. Thus, these high percentages suggest that the Sharia platform (C) constitutes the most dominant causal pathway between $\mathrm{A}$ and $\mathrm{B}$, and thus minimizing the role of any omitted variable (Condition 3 ).

\section{Correlational Analysis of the Support for a Radical Agenda and Homegrown Jihadist Groups}

In Table 2 (Row 3), where majority of Muslims favored Sharia as the law of the land $(80.8 \%$ average), the role of religious leaders as religious judges (76.0\% average), and corporal punishment (59.3\% average), homegrown Salafi militant groups had a strong presence in all (Table 1) but two of the nations (Malaysia and Jordan). Conversely, in Table 2 (Row 2), where only a minority favored Sharia as the law of the land with corresponding averages of $22.4 \%$, $22.9 \%$, and $16.3 \%$, respectively, in all but two of them (Turkey and Lebanon), homegrown jihadist groups had either a weak presence or none at all (Table 1). ${ }^{93}$ The extent of violent militancy in Turkey and Lebanon was strong likely due to the erstwhile Islamic State's ability in next-door neighbor Syria to form affiliations with homegrown jihadist groups. ${ }^{94}$

\section{Discussion}

The issues of significant concern in terrorism studies are establishing causation and the use of quality primary data. ${ }^{95}$ On these fronts, this study attempts to bridge the gap by starting with a theory that identified a causal pathway, invoking Kosovo as control, and utilizing the Pew data. Despite the variations in Sharia interpretations, the characterizations of the Sharia platform as both a moderator and (partial) causal mediator help us understand its dynamic in the radicalization process. The mediation analysis reveals that Sharia's influence makes religious leaders far more effective in propagating the radical agenda. Moreover, its moderating effect determines the strength of the relationship between religious leaders and the radical agenda. Interestingly, even in the subset of the population that does not favor Sharia as the law of the land, the Sharia platform still acts as a mediator. However, in the subset of the population that favors Sharia, its moderating influence is missing. Unlike most scholars who have associated Saudi Arabia's worldwide propagation of Wahhabism with the onset of Salafi extremism, ${ }^{96}$ some have opined - without providing alternate explanations of the newfound Wahhabi-style radicalization of the concerning communities - that it did not. ${ }^{97}$ However, the use of Kosovo as the control group here goes beyond such opinions.

Is Sharia the only plausible theme behind the onset of Salafi radicalism, or are there others? For a theme to play a role in the theory, it must be prominent (not obscure), part of the ongoing 
conversation, and associated with Wahhabism. Moreover, religious leaders, their flocks, and Saudi Arabia must have a significant interest in this theme. News reports on Muslim communities - covering religious leaders, the Muslim public worldwide, and Saudi Arabia — as well as think tank and survey reports/results can help identify prominent, newsworthy topics of conversations involving religion. Accordingly, Sharia is indeed one such theme, if not the only dominant theme, if the strength of the correlations is any indication. As noted in the previous section, Sharia also constitutes a dominant causal pathway or mechanism due to it being a religious leader's interpretation of Islam and a framework for espousing radical agendas.

Both directly and through the mediating effect of the Sharia platform, religious leaders are propagating radical agendas. Did a confounding variable affect the extent of correlations? A confounding variable must not lie in the causal pathway, have an independent relationship with the dependent variable (including possible causation), have an association with the independent or the mediating variable (but not as their proxy or surrogate), and that it must not be the result of the independent/mediating/dependent variables. ${ }^{98}$ The premise that confounding bias is minor in the worst-case scenario is supported by the data from Kosovo (Table 1), where A is $26 \%$, and B is $28 \%$ for those who believed in the idea of Sharia as the law of the land, but are meager $6 \%$ and $6 \%$, respectively, when Sharia bias is minimized (leaving only religious leaders' and the potential confounder's influences to remain). Moreover, due to the requirement that any potential confounder must be associated with Wahhabism, it is unlikely that a confounder even exists, independent of Sharia's or religious leaders' influences due to their preeminence as the themeenablers combination that dictates the Wahhabi ideology (Condition 3).

Another issue is determining the link between radicalism and extremism, as outlined in the theory. The data outlined in Tables 1 and 2 reveal how the extent of public support for Sharia, religious leaders, and their radical agenda correlate with the strength of homegrown jihadist groups; they also show that a religion-invoking ideology based on Sharia is shared by jihadists, religious leaders, and a significant section of the public. These correlations support the explanation that when a homegrown jihadist group forms, its radical agendas increasingly resonate with many locals (for example, in Pakistan, those who support the radical agenda of hudud punishments are more supportive of militancy ${ }^{99}$ ), even if they are opposed to terrorism. (To be clear, only a small minority among the Salafists resort to violence, ${ }^{100}$ even if the majority of them believe in the idea of Sharia as the law of the land-for instance, in Iraq where $91 \%$ support the idea of Sharia as the law of the land (Table 1), only $7 \%$ said that suicide bombings and other forms of violence against civilians in defense of Islam is often or sometimes justified. ${ }^{101}$ ) In addition, religious leaders who hold leadership positions in jihadist groups act as a bridge to the public. The correlations can also explain how impressionable young men may be recruited as future jihadists: those who voice support for radical agendas spearheaded by jihadist groups may sway newcomers, even if new entrants are not motivated by the associated radical ideologies, are unfamiliar with them, ${ }^{102}$ or are mostly ignorant of the religion as a whole. ${ }^{103}$ Hence, the extent of radicalism or belief in radical agendas is an important precursor to violent extremism or terrorism in that community, as outlined in the proposed theory. 
When the majority favored Sharia, even those who did not favor Sharia found religious leaders and their agendas receptive (Table 2, Row 3), and the minority in the associated communities can be susceptible to extremism (Table 1, Column 10). An explanation consistent with data is that as Sharia grew in popularity, as its primary interpreters, religious leaders grew more influential, and so did the agendas they sanctioned based on Sharia. In such an environment, radical preachersthose without formal training in theology - that leverage Sharia's local popularity to advance radical agendas have arisen. ${ }^{104}$ However, when less than the majority favored Sharia, religious leaders and their agendas found less receptive audiences (Table 2, Row 2). Those who did not favor Sharia as the law of the land were approximately three times less likely to be supportive of religious leaders (16.3\% vs. $53.3 \%)$ and their radical agenda (11.1\% vs. $39.1 \%)$ than those who did favor Sharia (Table 2). Under these circumstances, jihadist groups found it difficult to sustain themselves or find willing recruits (Table 1, Column 10), regardless of the ills afflicting individuals or society. These data underscore the importance of the idea of Sharia as the law of the land vis-à-vis Salafi radicalism and extremism.

As discussed in the Introduction section, when even secular risk factors ${ }^{105}$ make individuals susceptible to embracing (Salafi) extremism, the Salafi ideology itself must have first taken root in such communities. The usefulness of the proposed theory is that it allows us to recast or enhance our understanding of Salafi extremism by delineating why and how the ideology takes root. Moreover, it helps us understand why the jihadist groups have so quickly emerged — thanks to the ideological simplicity of Salafism - in contrast to the quotes of Walter and Taspinar noted in the Introduction section. From the utility viewpoint, the theme-enablers conceptual framework and identifying the theme with mediating and moderating influence should apply to a broad class of social movements. Several ideas have been outlined here to develop a theory using the framework and validate it for an emerging social phenomenon.

Although this study does not discuss direct evidence, the indirect evidence discussed here points to Sharia's growing popularity over time, thanks to Wahhabism's propagation. Another Pewtype study would be useful in this regard. The reasonable assumption that the dynamic associated with Wahhabism's propagation vis-à-vis the variables and confounding is similar across the geographical and social divides may require further scrutiny. Although this study was conducted for only one specific radical agenda, elevated support levels among those who support the idea of Sharia as the law of the land were also observed for two other radical agendas covered in the Pew study, ${ }^{106}$ - namely, stoning those who committed adultery and favoring the death penalty for those leaving Islam. A limitation is that this theory is specific to explaining Salafi extremism, but not other forms of religious or secular extremism. Nonetheless, this article is a preliminary step in identifying Sharia as the dominant theme, and it could form a guide for future surveys that compare the impact of various themes or causal pathways in detail.

Here is an example of how Salafism's dynamics, revealed by the theory, force a rethink of conventional wisdom. Scholars have called on Western governments to help address the secondary or "underlying" causes, or "factors" such as weak governance and persistent 
grievances, that fuel local support for Salafi jihadist groups in unstable nations such as Iraq. ${ }^{107}$ For example, Jones et al. make the following recommendation: "An important—perhaps the most important - component of Western policy should be helping regimes that are facing terrorism improve governance and deal more effectively with economic, sectarian, and other grievances that have been manipulated by Salafi-jihadist groups." 108

However, this study provides an alternate explanation of why the public looks up to jihadist groups: the factors' relevance could have stemmed from the public's perception that local jihadist groups can help solve social problems by strictly governing under Sharia law. Supporting the above premise is the data that governance issues that are all too common in the countries listed in Table 1 did not necessarily lead to homegrown jihadist groups' sustenance unless the corresponding countries had high support levels for religious leaders and Sharia (91\% in Iraq). ${ }^{109}$ Moreover, the community's governance issues could have stemmed, in part, from the onset of radicalization and its subsequent movement away from modernity. Indeed, when religious leaders dictate how people should live in such communities or how the community should evolve through Sharia interpretations, providing good governance can become challenging. Hence, policies should aim at the primary cause of Salafi extremism, and scholars should be cautious about emphasizing the importance of secondary or so-called "underlying" causes.

To the extent that religious leaders use the Sharia platform to advance the agendas they favor, there are broad implications to the proposed theory that are outside the scope of this article. ${ }^{110}$ That there is no consensus understanding of the causal pathways behind religion-invoking extremism is reflected in the counterterrorism policies of the United States, Austria, and Kosovo. ${ }^{111}$ Having said that, the proposed theory and the Sharia platform's identification as both a causal mediator and moderator have counterterrorism and deradicalization policy implications. Accordingly, it would seem that rolling back the extent of radicalization, and reducing the presence of jihadist groups, involves negating the religious ideological ecosystem built by Wahhabism's propagation — which appears to be self-sustaining, despite reduced support from Saudi Arabia. ${ }^{112}$ The proposed theory, backed by the empirical data analysis provided here, suggests that addressing Wahhabism's and Salafism's ideological impact, which considers religious leaders' Sharia interpretations as all-encompassing divine law — as it forms the basis of a coherent ideology (see above) - is crucial in this task. The underlying strategy is to wean the public away from its dependence on religious leaders who dictate the people's outlook and decision-making based on the leaders' supposed expertise with the all-encompassing "divine" guide to a life of Sharia. Instead, nudge the public to develop an outlook and make decisions based on their own experiences, observations, and interactions.

If reducing Sharia's impact is indeed the desired outcome for undercutting the appeal of the ideology of Salafism, one must propagate the idea that Sharia interpretations are mostly religious leaders' opinions of Islam. Moreover, as noted before, even in Saudi Arabia, these interpretations are often contradictory, ${ }^{113}$ and in some cases, they are considered strange even by local religious authorities. ${ }^{114}$ Such a campaign should help reverse the onset of radicalization, thereby helping 
the affected communities to reembrace modernity — after all, unfathomable as it may seem now, before the onset of radicalization, in the 1950s, 60s, and even in the 70s, it was common for Kabul women to wear Western clothing and mix freely with men. ${ }^{115}$ However, the Taliban's resurgence in Afghanistan ${ }^{116}$ clarifies that defeating Salafi jihadist groups requires more than kinetic force; it is indeed a must to counter extremist ideologies.

\section{Notes on the Contributor}

Moorthy Muthuswamy is an independent scholar of terrorism with a doctorate in nuclear physics from Stonybrook University. He has published articles and a book on religion-invoking extremism, in addition to over 20 articles in physics. Email: moorthym@comcast.net.

\section{ORCID}

Moorthy Muthuswamy: https://orcid.org/0000-0002-2849-7077

\section{Notes}

[1] See, for example, Roel Meijer, Global Salafism: Islam's New Religious Movement, Oxford: Oxford University Press (2010); Shiraz Maher, Salafi Jihadism: The History of an Idea, London: Hurst (2016); Seth Jones, "A Persistent Threat: The Evolution of al Qa'ida and Other Salafi Jihadists," RAND, 2014; URL: http://www.rand.org/pubs/research_reports/RR637.html; Seth Jones et al., "The Evolution of the Salafi Jihadist Threat," CSIS, November 20, 2018; URL: https://www.csis.org/analysis/evolution-salafi-jihadist-threat. This article does not differentiate the Taliban from Salafis due to their similar views of Sharia and armed jihad. See Mark Joyella, “Taliban Tells CNN's Clarissa Ward 'Islamic Law Will Come Not Just To Afghanistan, But All Over The World'," The Forbes, August 15, 2021; URL:

https://www.forbes.com/sites/markjoyella/2021/08/15/taliban-tells-cnns-clarissa-ward-islamiclaw-will-come-not-just-to-afghanistan-but-all-over-the-world/?sh=4ad2898612cf.

[2] Barbara Walter, “The Extremist's Advantage in Civil Wars,” International Security, 42(2) (2017): 39 .

[3] Omer Taspinar, "Fighting Radicalism, not 'Terrorism': Root Causes of an International Actor Redefined," SAIS Review of International Affairs, 29(2) (2009): 76; see also the following review articles: Alex Schmid, "Radicalisation, De-Radicalisation, Counter-Radicalisation: A Conceptual Discussion and Literature Review," The International Centre for Counter-Terrorism, 4(2) (2013); URL: https://www.icct.nl/download/file/ICCT-Schmid-Radicalisation-DeRadicalisation-Counter-Radicalisation-March-2013_2.pdf.

[4] John Mearsheimer and Stephen Walt, "Leaving Theory Behind: Why Simplistic Hypothesis Testing is Bad for International Relations," European Journal of International Relations, 19(3) (2013): 430, 448, 437.

[5] Schmid, v (see note 3). See the references therein for a detailed discussion. 
[6] Colin Beck, "The contribution of social movement theory to understanding terrorism," Sociology Compass, 2(5) 2008: 1565-81.

[7] Bruce Hoffman, Inside Terrorism, New York: Columbia University Press (2006), 3.

[8] Louise Richardson, What Terrorists Want: Understanding the Enemy, Containing the Threat, New York: Random House (2007), 4.

[9] Bruce Livesey, “The Salafist Movement," January 25, 2005; URL:

https://www.pbs.org/wgbh/pages/frontline/shows/front/special/sala.html.

[10] Bernard Haykel, "Salafis," in The Princeton Encyclopedia of Islamic Political Thought, eds Gerhard Bowering et al., Princeton: Princeton University Press (2012), 483-484.

[11] Livesey (see note 9); See also Gilles Kepel, "PBS Interview," September 26, 2004; URL: https://www.pbs.org/wgbh/pages/frontline/shows/front/interviews/kepel.html. For details on other forms of radical Islamist movements, see Hamid Enayat, Modern Islamic Political Thought, New York: American Council of Learned Societies (2014).

[12] Jones, 27 (see note 1); Jones et al., 11 (see note 1); see also, Nils Gleditsch and Ida Rudolfsen, “Are Muslim Countries More Prone to Violence?" Research and Politics, 3(2) 2016: $1-9$.

[13] Walter, 16 (see note 2). Assaf Moghadam makes the case that Salafi jihadism is an ideology, see "The Salafi-Jihad as a Religious Ideology," CTC Sentinel, 1(3) (2008).

[14] See, for example, Abd Ar-Rahman Doi and Abdassamad Clarke, Shariah Islamic Law, London: Ta-Ha (2008).

[15] Jessica Rivinis, "Majority of 2013 Terrorist Attacks Occurred in Just a Few Countries," START, 2014; URL: http://www.start.umd.edu/ news/majority-2013-terrorist-attacks-occurredjust-few-countries; see the following article for computation of the percentages: Moorthy Muthuswamy, "The Role of Sharia and Religious Leaders in Influencing Violent Radicalism," Science, Religion \& Culture, 3(1) (2016): 17; URL: http://researcherslinks.com/currentissues/The-Role-of-Sharia-and-Religious-Leaders-in-Influencing-Violent-Radicalism/9/5/180.

[16] Ibid.; ibid.

[17] See Thomas Friedman, “Our Radical Islamic BFF, Saudi Arabia,” New York Times, September 2, 2015; URL: http://www.nytimes.com/2015/09/02/opinion/thomas-friedman-ourradical-islamic-bff-saudi-arabia.html; Claude Moniquet, "The Involvement of Salafism/Wahhabism in the Support and Supply of Arms to Rebel Groups Around the World," 2013; URL: http://www.europarl.europa.eu/RegData/etudes/etudes/join/2013/457137/EXPOAFET_ET(2013)457137_EN.pdf; Peter Mandaville and Shadi Hamid, "Islam as Statecraft: How Governments Use Religion in Foreign Policy," November 2018; URL:

https://www.brookings.edu/wp-content/uploads/2018/11/FP_20181116_islam_as_statecraft.pdf; David Commins, The Wahhabi Mission and Saudi Arabia, NY: Tauris (2006); Haykel, 484 (see note 10$)$.

[18] See Thomas Hegghammer, "The Rise of Muslim Foreign Fighters: Islam and the Globalization of Jihad," International Security, 35(3) (2010): 81. I used the following data to signify the start of worldwide propagation of Wahhabism: in the 1980s, the kingdom's 70 or so 
embassies around the world were tasked with propagating Wahhabism by building new mosques or by persuading the existing ones (see Robert Lacey, Inside the Kingdom: Kings, Clerics, Modernists, Terrorists, and the Struggle for Saudi Arabia, NY: Viking (2009), 95).

[19] MEMRI, "Saudi Government Paper: 'Billions Spent by Saudi Royal Family to Spread Islam to Every Corner of the Earth'," March 27, 2002; URL:

http://www.memri.org/report/en/0/0/0/0/0/0/638.htm.

[20] ICG, “Can Saudi Arabia Reform Itself?,” July 14, 2004; URL:

https://d2071 andvip0wj.cloudfront.net/28-can-saudi-arabia-reform-itself.pdf, accessed

November 4, 2020.

[21] Haykel, 484 (see note 10); see also Mohamed Ali and Muhammad Sudiman, "Salafis and Wahhabis: Two Sides of the Same Coin?," October 12, 2016; URL:

http://www.eurasiareview.com/12102016-salafis-and-wahhabis-two-sides-of-the-same-coinanalysis/.

[22] See Ian Black, "Syria Crisis: Saudi Arabia to Spend Millions to Train New Rebel Force," Guardian, November 7, 2013; URL: http://www.theguardian.com/world/2013/nov/07/syriacrisis-saudi-arabia-spend-millions-new-rebel-force; Guardian, "US Embassy Cables: Hillary Clinton Says Saudi Arabia 'a Critical Source of Terrorist Funding'," December 5, 2010; URL: http://www.theguardian.com/world/us-embassy-cables-documents/242073.

[23] USCIRF, “Saudi Arabia: USCIRF Confirms Material Inciting Violence, Intolerance Remains in Textbooks Used at Saudi Government's Islamic Saudi Academy," June 11, 2008; URL: http://www.uscirf.gov/news-room/press-releases/saudi-arabia-uscirf-confirms-materialinciting-violence-intolerance-remains.

[24] Peter Neumann, "Foreign Fighter Total in Syria/Iraq Now Exceeds 20,000," ICSR, January 26, 2015; URL: https://icsr.info/2015/01/26/foreign-fighter-total-syriairaq-now-exceeds-20000surpasses-afghanistan-conflict-1980s/.

[25] MWL, “Muslim World League," 2014; URL:

http://www.themwl.org/Profile/default.aspx?1=EN\#cred, accessed January 19, 2014; The MWL has been funded by the Saudi government since its inception in the 1960s to promote Saudi ideology, including Wahhabism, see Werner Ende and Udo Steinbach, Islam in the World Today: A Handbook of Politics, Religion, Culture, and Society, Ithaca, NY: Cornell University Press (2011).

[26] Muhammad Ali Harakan, "Duty of Implementing the Resolutions," Journal of the Muslim World League, 6 (1980): 48-49; Hegghammer, 83 (see note 18).

[27] See Carlotta Gall, "How Kosovo was Turned into Fertile Ground for ISIS," New York Times, May 21, 2016; URL: http://www.nytimes.com/2016/05/22/world/europe/how-the-saudisturned-kosovo-into-fertile-ground-for-isis.html; Krithika Varagur, The Call: Inside the Global Saudi Religious Project, NY: Columbia University Press (2020). This book reveals that the Wahhabi Islam emanating from and supported by Saudi Arabia had been the dominant one.

[28] David Waterman, "Saudi Wahhabi Imperialism in Pakistan: History, Legacy, Contemporary Representations and Debates," Societal Studies, 6(2) (2014): 242-58. 
[29] See Esther Eijk, "Sharia and National Law in Saudi Arabia," in Sharia Incorporated: A Comparative Overview of the Legal Systems of Twelve Muslim Countries in Past and Present, eds Jan M. Otto, Leiden: Leiden University Press (2010), 139-180.

[30] Ibid., 157; For a view of religious leaders' role in the Saudi power structure, see Global Security, "Council of Senior Ulama," URL:

http://www.globalsecurity.org/military/world/gulf/sa-ulama.htm, accessed November 8, 2020.

[31] Eijk, 166-67 (see note 29).

[32] Ibn Baz, "Fatwas of Ibn Baz,"; URL:

http://alifta.gov.sa/En/IftaContents/IbnBaz/Pages/FatawaDetails.aspx?View=Page\&PageID=475 \&CultStr=en \&PageNo=1\&NodeID=1\&BookID=14, accessed November 11, 2020.

[33] Huda al-Saleh, "52 Saudi Clerics, Scholars Call to Battle Russian Forces in Syria," alArabia, October 5, 2015; URL: https://english.alarabiya.net/en/News/middleeast/2015/10/05/Fifty-two-Saudi-clerics-scholars-call-for-fight-against-Russian-forces-in-Syria.

[34] See Neil Macfarquhar, "Fatwa Overload: Why Middle East Sheikhs are Running Amok," Foreign Policy, April 17, 2009; URL: http://foreignpolicy.com/2009/04/17/fatwa-overload/.

[35] See Borzou Daragahi, "Saudi Arabia: Authorities Tighten Restrictions on Clerical Fatwas and Sermons," Los Angeles Times, August 27, 2010; URL:

http://latimesblogs.latimes.com/babylonbeyond/2010/08/saudi-arabia-authorities-tighten-crackdown-against-clergy.html.

[36] Ibid.

[37] Christopher Boucek, "Saudi Fatwa Restrictions and the State-Clerical Relationship," Carnegie Endowment, October 27, 2010; URL: http://carnegieendowment.org/2010/10/27/ saudi-fatwa-restrictions-and-state-clerical-relationship/6b81; see also, Marwa Rashad, "Saudi Arabia Announces New Judicial Reforms in a Move Towards Codified Law," Reuters, February 8, 2021; URL: https://www.reuters.com/article/us-saudi-judiciary/saudi-arabia-announces-newjudicial-reforms-in-a-move-towards-codified-law-idUSKBN2A82E6.

[38] Michael King and Donald M. Taylor, "The Radicalization of Homegrown Jihadists: A Review of Theoretical Models and Social Psychological Evidence," Terrorism and Political Violence, 23(4) (2011): 615.

[39] See Arturo Varvelli, "Jihadist Hotbeds: Understanding Local Radicalization Processes," Italian Institute for International Political Studies, 2016; URL:

http://www.ispionline.it/sites/default/files/pubblicazioni/jihadist.hotbeds_ebook_0.pdf.

[40] Sarah L. Desmarais et al., "The State of Scientific Knowledge Regarding Factors Associated with Terrorism," Journal of Threat Assessment and Management, 4(4) (2017): 186.

[41] Ibid., 180.

[42] Ibid., 180.

[43] Moorthy Muthuswamy, “A Conceptual Framework of Salafi Radicalization: An Underlying Theme and its Enablers," Science, Religion \& Culture, 5(1) (2018): 53; URL: 
https://researcherslinks.com/current-issues/A-Conceptual-Framework-Salafi-

Radicalization/9/1/1816.

[44] See Eijk (note 29); Toni Johnson and Mohammed Aly Sergie, "Islam: Governing Under Sharia," Council on Foreign Relations, July 25, 2014; URL:

https://www.cfr.org/backgrounder/islam-governing-under-sharia; Frank Vogel, Islamic Law and the Legal System: Studies of Saudi Arabia, Leiden: Brill (2000).

[45] See John Calvert, Sayyid Qutb and the Origins of Radical Islamism, New York: Columbia University (2010); Join Owen, Confronting Political Islam: Six Lessons from the West's Past, Princeton, NJ: Princeton University (2014).

[46] Steven Kull et al., "Muslims Believe US Seeks to Undermine Islam,” World Public Opinion, April 24, 2007; URL: http://worldpublicopinion.net/muslims-believe-us-seeks-toundermine-islam/. See Eijk (note 29), for details regarding the application of Sharia law in the countries mentioned.

[47] Ibid., 15.

[48] James Bell et al., "The World's Muslims: Unity and Diversity," Pew Research Center, August 9, 2012, 8 and 42; URL: https://www.pewresearch.org/wp-

content/uploads/sites/7/2012/08/the-worlds-muslims-full-report.pdf.

[49] See, for example, Baladas Ghoshal, "Arabization: The Changing Face of Islam in Asia," India Quarterly, 66(1) (2010): 69-89; Varagur (see note 27).

[50] See, for example, Walter (note 2).

[51] Walter, 15 (note 2) defines ideology as a set of beliefs about the proper order of society and how it can be achieved. See also the following references regarding the role of religious ideologies in spawning terrorism: Mark Juergensmeyer, Terror in the Mind of God: The Global Rise of Religious Violence, Berkeley: University of California Press (2000); the following scholarship examines the role of ideology in terrorists' target selection. See C. Drake, "The Role of Ideology in Terrorists' Target Selection," Terrorism and Political Violence, 10(2) (1998): 5385. However, unlike the above references, the following one discusses Sharia forming the basis of Salafi ideology: Craig Whiteside, Anas Elallame, Moorthy Muthuswamy, and Aram Shabanian, "The Islamic State's Department of Soldiers," GWPE-ISIS Files, April, 2021, 22; URL: https://isisfiles.gwu.edu/downloads/q237hr95t.

[52] Following Muthuswamy (see note 43), the designation Muslim "religious leaders" applies to those who, through formal religious training or self-study, are recognized as such by their communities; the term entails having a command of the scriptures and Islam's history.

[53] See MEMRI, "Conference Issues Declaration against Terror, Blames 'Tyrant and Colonial Master of the West [i.e. U.S.]' for Aggression in Muslim World,” April 9, 2008; URL:

https://www.memri.org/reports/indian-clerics-anti-terror-conference-issues-declaration-againstterror-blames-tyrant-and.

[54] Ash-Shariah wal-Hayat is a television program on Sharia law and the connections between Sharia law and everyday life. See Von Smoltczyk, "The Voice of Egypt's Muslim Brotherhood," Speigel International, February 15, 2011; URL: 
https://www.spiegel.de/international/world/islam-s-spiritual-dear-abby-the-voice-of-egypt-smuslim-brotherhood-a-745526.html.

[55] Muthuswamy, 58 (see note 43).

[56] Open Society Institute, "British Muslims and Education," 2005; URL:

http://www.fairuk.org/docs/OSI2004\%207_Education.pdf; Duncan Gardham and Tom Whitehead, "Extremism Unchecked in Schools, Secret Briefing Reveals," Telegraph, December 31, 2012.

[57] Innes Bowen, “Who Runs our Mosques?," Spectator, June 14, 2014; URL:

https://www.spectator.co.uk/article/who-runs-our-mosques-; Tom Wilson, "Foreign Funded Islamist Extremism in the UK," Henry Jackson Society, July 2017; URL:

http://henryjacksonsociety.org/wp-content/uploads/2017/07/Foreign-Funded-IslamistExtremism-final.pdf.

[58] Munira Mirza, Abi Senthilkumaran, and Zein Ja'far, "Living Apart Together: British Muslims and the Paradox of Multiculturalism," Policy Exchange, 2007; URL: https://policyexchange.org.uk/wp-content/uploads/2016/09/living-apart-together-jan-07.pdf.

[59] Muthuswamy, 53 (see note 43).

[60] The proposed theory is a modified version of the one by proposed by Muthuswamy (ibid., 53). Muthuswamy used the words "to advance radical Islamist agendas." The word "Islamist" is removed here as it is unlikely that many followers distinguish between non-Islamist (such as a geopolitical grievance) and Islamist (religion-based) radical agendas. Moreover, religious leaders have legitimized geopolitical grievances through fatwas. For example, the influential Palestinian Islamic scholar Abdullah Azzam issued a fatwa sanctioning Muslims to fight against the Soviet Union's occupation of Afghanistan (https://english.religion.info/2002/02/01/document-defenceof-the-muslim-lands/ (accessed November 2, 2020). Muthuswamy's theory also does not describe the transition from radicalism to extremism.

[61] See Austin B. Hill, "The Environment and Disease: Association or Causation?," Proceedings of the Royal Society of Medicine, 58 (1965): 295-300; See, for example, the following reference on the role of a causal variable: Reuben Baron and David Kenny, "The Moderator-Mediator Variable Distinction in Social Psychological Research: Conceptual, Strategic, and Statistical Considerations," Journal of Personality and Social Psychology, 51(6) (1986): 1173-82.

[62] See Baron and Kenny (note 61).

[63] Bryan T. Karazsia and Kristoffer S. Berlin, "Can a Mediator Moderate? Considering the Role of Time and Change in the Mediator-Moderator Distinction," Behavior Therapy, 49 (2018): $12-20$.

[64] See, Baron and Kenny (note 61).

[65] Moderators tend to be independent variables, see Baron and Kenny, 1174 (note 61).

[66] James Bell et al., "The World's Muslims: Religion, Politics and Society," Pew Research Center, April 30, 2013; URL: http://www.pewforum.org/files/2013/04/worlds-muslims-religionpolitics-society-full-report.pdf. 
[67] Ibid., 7.

[68] For details on corporal punishments and their context in Sharia, see Mark Cammack, "Islamic Law and Crime in Contemporary Courts," Berkeley Journal of Middle Eastern \& Islamic Law, 4(1) (2011): 1-15.

[69] Other than the ones in the sixth and ninth columns, the data entered in the first nine columns were taken from Bell et al. (see note 66). The entries in Column 6 of Table 1 was computed using this equation: Column 6 entry $=100 *($ Column 4 entry - Column 2 entry*Column 5 entry*0.01)/(100 - Column 2 entry). The entries in Column 9 of Table 1 was computed using this equation: Column 9 entry $=100 *$ (Column7 entry - Column 2 entry*Column8 entry*0.01)/(100 Column 2 entry). There is at least $10 \%$ uncertainty associated with the computed entries and more so with those of smaller size. This error stems from the fact that many respondents refused to answer or did not know what to answer. As a result, they were included as part of the statistics of the negative response to the question. See Muthuswamy, 72 (note 43) for details.

[70] Bell et al., 150 (see note 66).

[71] The "no" designation reflects either no known presence of jihadist groups or only a meager following for transnational groups such as al-Qaeda and without the occurrence of a terrorist attack in the past five years. The "weak" one indicates that the country has not witnessed any major terrorist attacks by homegrown jihadist groups in the past five years, even though it has an active presence of such groups. The "strong" one reflects at least one major act of terrorism within the past five years by homegrown jihadists. See Muthuswamy, 17 (note 15) for details.

[72] al-Saleh (see note 33); Gall (see note 27); for example, in Pakistan, between ten percent and fifteen percent of the religious schools (madrasas) run by religious leaders are involved in either sectarian militancy or international terrorism, see Zahid Hussain, Frontline Pakistan: The Struggle with Militant Islam, New York: Columbia University (2008), 79.

[73] Joseph Carter, Shiraz Maher, and Peter Neumann, "Greenbirds: Measuring Importance and Influence in Syrian Foreign Fighter Networks," ICSR, April 22, 2014; URL: https://icsr.info/2014/04/22/icsr-report-inspires-syrian-foreign-fighters/.

[74] Richard Nielsen, Deadly Clerics: Blocked Ambition and the Paths to Jihad, London: Cambridge University Press (2017), 121.

[75] Youssef Aboul-Enein, “The Late Sheikh Abdullah Azzam's Books: Radical Theories on Defending Muslim Land through Jihad," The Combating Terrorism Center, June 2010; URL: https://ctc.usma.edu/wp-content/uploads/2010/06/Azzam_part_3.pdf.

[76] Carlotta Gall, "Mullah Muhammad Omar, Enigmatic Leader of Afghan Taliban, Is Dead," New York Times, July 30, 2015; URL:https://www.nytimes.com/2015/07/31/world/asia/mullahmuhammad-omar-taliban-leader-afghanistan-dies.html.

[77] BBC News, "Profile: Abu Bakr al-Baghdadi," May 15, 2015; URL: https://www.bbc.com/news/world-middle-east-27801676.

[78] Claire Felter, "Nigeria's Battle with Boko Haram," Council on Foreign Relations, August 8, 2018; URL: https://www.cfr.org/backgrounder/nigerias-battle-boko-haram. 
[79] KIPRED, "What Happened to Kosovo Albanians: The Impact of Religion on the Ethnic Identity in the State building-period," 2016, 8; URL:

www.kipred.org/repository/docs/What_happened_to_Kosovo_Albanians_740443.pdf.

[80] Control here consists of a population that was not subjected to the influence of interest.

[81] KIPRED, 8 (see note 79).

[82] Ghoshal (see note 49); Varagur (see note 27).

[83] Gilles Kepel, Jihad: The Trail of Political Islam, London: I.B. Taurus (2002), 239.

[84] KIPRED (see note 79).

[85] KCSS, "Report Inquiring into the Causes and Consequences of Kosovo Citizens' Involvement as Foreign Fighters in Syria and Iraq," 2015, 30-31; URL:

http://www.qkss.org/repository/docs/Report_inquiring_into_the_causes_and_consequences_of_ Kosovo_citizens'_involvement_as_foreign_fighters_in_Syria_and_Iraq_307708.pdf; See also Wilson (note 57).

[86] Ibid., 56.

[87] Gall (see note 27).

[88] The Republic of Kosovo, "Strategy on Prevention of Violent Extremism and Radicalisation Leading to Terrorism 2015-2020," 2015, 14; URL: www.kryeministri-

ks.net/repository/docs/STRATEGY_parandalim___ENG.pdf.

[89] Adrian Shtuni, "Dynamics of Radicalization and Violent Extremism in Kosovo," USIP, December 2016, 10; URL: https://www.usip.org/publications/2016/12/dynamics-radicalizationand-violent-extremism-kosovo.

[90] The formula used for computing the correlation coefficient for variables A and B is the standard deviation of $\mathrm{A}$ and $\mathrm{B} /($ standard deviation of $\mathrm{A}$ *standard deviation of $\mathrm{B}$ ). It ranges between -1 and 1 , reflecting negative and positive correlations, respectively.

[91] Michael Sobel, "Asymptotic intervals for indirect effects in structural equations models," in Sociological methodology, ed S. Leihart, San Francisco: Jossey-Bass (1982), 290-312. The Sobel test P-values were computed using this portal: http://www.quantpsy.org/sobel/sobel.htm.

[92] Andrew Hayes, Introduction to Mediation, Moderation, and Conditional Process Analysis, New York: Guilford Press (2017); Jeremy Dawson, "Moderation in Management Research: What, Why, When, and How," J. Bus. Psychology, 29 (2014): 1-19.

[93] The strength of homegrown jihadist groups reflects the public support for groups that are fighting to implement radical agendas based on religious ideologies espoused by religious leaders. The entries presented in the tenth column of Table 1 are partly based on the 2014 START database. For details, see Muthuswamy, 17 (note 15).

[94] Raziye Akkoc, "Ankara Bombing: Claims Emerge that Culprit could be Brother of Terrorist Involved in Previous Atrocity," Telegraph, October 11, 2015; URL: https://www.telegraph.co.uk/news/worldnews/europe/turkey/11925064/Ankara-bombingClaims-emerge-that-culprit-could-be-brother-of-terrorist-involved-in-previous-atrocity.html; 
Greg Botelho, Paul Cruickshank, and Catherine Shoichet, "Beirut Suicide Bombings Kill 43; Suspect Claims ISIS Sent Attackers," CNN, November 16, 2015; URL: https://www.cnn.com/2015/11/12/middleeast/beirut-explosions/index.html.

[95] See Desmarais et al. (see note 40); Bart Schuurman, "Research on Terrorism, 2007-2016: A Review of Data, Methods, and Authorship.” Terrorism and Political Violence, 32(5) (2018): 1011-1026.

[96] See Gall (27); Varagur (see note 27); Wilson, 1 (see note 57); Scott Shane, "Saudis and Extremism: 'Both the Arsonists and the Firefighters'," New York Times, August 25, 2016; URL: https://www.nytimes.com/2016/08/26/world/middleeast/saudi-arabia-islam.html; MEMRI (see note 19); Saudi Arabia and other gulf countries "effectively paid for the rise of the pan-Islamist movement by funding the international Islamic organizations" and that generally the Saudi charities had the deepest pockets, see Thomas Hegghammer, The Caravan: Abdallah Azzam and the Rise of Global Jihad, Cambridge: Cambridge University Press (2020), 506, 195. Saudi Arabia also has had an opportunity to proselytize millions of foreign pilgrims.

[97] See, for example, Natana Delong-bas, Wahhabi Islam: From Revival and Reform to Global Jihad, Oxford: Oxford University Press (2008).

[98] Andrea C Skelly, Joseph R Dettori, and Erika D Brodt, "Assessing bias: the Importance of Considering Confounding," Evidence-Based Spine-Care Journal, 3(1) (2012): 9-12.

Confounding can also occur in the pathway between causal and dependent variables. See Charles Judd and David Kenny, "Process Analysis: Estimating Mediation in Treatment Evaluations," Evaluation Review, 5(5) (1981): 602-19.

[99] Christine Fair, Rebecca Littman, and Elizabeth R. Nugent, "Conceptions of Shari'a and Support for Militancy and Democratic Values: Evidence from Pakistan,” Political Science Research and Methods, 6(3) (2018): 443.

[100] See Haykel (note 10).

[101] Bell et al., 29 (see note 66); Randy Borum, "The Etiology of Radicalization," in The Handbook of the Criminology of Terrorism, eds Gary LaFree and Joshua D. Freilich, Hoboken: Wiley-Blackwell (2017), 28.

[102] Clark McCauley, "Testing Theories of Radicalization in Polls of U.S. Muslims," Analyses of Social Issues and Public Policy, 12(1) (2012): 309.

[103] Scott Gates and Sukanya Podder, "Social Media, Recruitment, Allegiance, and the Islamic State," Perspectives on Terrorism, 9(4) (2015): 109; URL:

http://www.terrorismanalysts.com/pt/index.php/pot/article/view/446/html.

[104] Kevin Sullivan, "Police Call Him an ISIS Recruiter. He Says He's Just an Outspoken Preacher," Washington Post, November 23, 2015;

URL:https://www.washingtonpost.com/world/national-security/police-call-him-an-isis-recruiterhe-says-hes-just-an-outspoken-preacher/2015/11/23/924d8f6e-8a15-11e5-9a07453018f9a0ec_story.html?

[105] Desmarais et al., 180 (see note 40).

[106] Bell et al. (see note 66). 
[107] Jones et al., 48 (see note 1); Katherine Zimmerman, "Beyond Counterterrorism: Defeating the Salafi Jihadist Movement," AEI, 2019, 2; URL: https:/www.aei.org/wp-

content/uploads/2019/10/Beyond-Counterterrorism.pdf.

[108] Jones et al., 1 (see note 1).

[109] Sharia is not the law of the land in Iraq, see Erik Jensen, "Introduction to the Laws of Iraq and Iraqi Kurdistan," Stanford Law School, 2013; URL:

https://law.stanford.edu/publications/introduction-laws-iraq-iraqi-kurdistan-series-overview/.

[110] See the following reference for examples of how religious leaders use the Sharia platform to advance the agenda of promoting religious education at the expense of a modern one: Moorthy Muthuswamy, "Sharia as a Platform for Espousing Violence and as a Cause for Waging Armed Jihad," in Sharia Law: From Oman to Oklahoma, Albany Government Law Review, 7(2) (2014): 347-78; URL: http://www.albanygovernmentlawreview.org/archives/Pages/articleinformation.aspx ?volume=7\&issue=2\&page=347; Muthuswamy (see note 43).

[111] "National Strategy for Counterterrorism of the United States of America," The White House, October 2018, 2; URL: https://www.whitehouse.gov/wp-

content/uploads/2018/10/NSCT.pdf; "The Austrian Strategy for the Prevention and Countering of Violent Extremism and De-Radicalisation," The Austrian Government, November 2018; URL: https://www.beratungsstelleextremismus.at/wp-content/uploads/2018/10/2241.pdf; The Kosovo Government (see note 88).

[112] See Krithika Varagur, "Saudi Arabia Is Redefining Islam for the World's Largest Muslim Nation," Atlantic, March 2, 2017; URL:

https://www.theatlantic.com/international/archive/2017/03/saudi-arabia-salman-visitindonesia/518310/.

[113] Macfarquhar (see note 34).

[114] Daragahi (see note 35).

[115] Ted Tornhill, "Women Lived Free in Afghanistan: Pictures Show How They Were Once Able to Study, Wear Skirts and Mix Freely with Men - Before Civil War, Invasion and the Taliban Enslaved Them," Daily Mail, January 23, 2014; URL:

https://www.dailymail.co.uk/news/article-2543902/Photos-just-free-women-AfghanistanTaliban-rule.html\#ixzz3sEGEi7W4.

[116] Joyella (note 1). 
Table 1: Public Support Levels for Sharia as the Law of the Land (SSL), a Political Role for Religious leaders (SRLP), Religious Leaders as Religious Judges (Combined (SRRF), Among those who Did (SRRS), and Did not (SRRN) Favor Sharia as the Law of the Land), Corporal Punishment (Combined (SCPF), Among those who Did (SCPS), and Did not (SCPN) Favor Sharia as the Law of the Land), and the Extent of Homegrown Jihadist Attacks (HJA)

\begin{tabular}{|l|l|l|l|l|l|l|l|l|l|}
\hline Country & SSL (\%) & SRLP (\%) & SRRF (\%) & SRRS (\%) & SRRN (\%) & $\begin{array}{l}\text { SCPF } \\
(\%)\end{array}$ & $\begin{array}{l}\text { SCPS } \\
(\%)\end{array}$ & $\begin{array}{l}\text { SCPN } \\
(\%)\end{array}$ & HJA \\
\hline Kosovo & 20 & 27 & 10 & 26 & 6 & 10 & 28 & 6 & No \\
\hline Albania & 12 & 17 & 11 & 55 & 5 & 9 & 43 & 4 & No \\
\hline Bosnia & 15 & 17 & 6 & 24 & 3 & 13 & 32 & 10 & No \\
\hline Kyrgyzstan & 35 & 46 & 44 & 65 & 33 & 37 & 54 & 28 & Weak \\
\hline Turkey & 12 & 36 & 14 & 48 & 9 & 12 & 35 & 9 & Strong \\
\hline Tajikistan & 27 & 28 & 33 & 66 & 21 & 20 & 40 & 13 & Weak \\
\hline Kazakhstan & 10 & 24 & 14 & 59 & 9 & 13 & 31 & 11 & Weak \\
\hline Azerbaijan & 8 & 14 & 8 & NA & NA & 6 & NA & NA & Weak \\
\hline Russia & 42 & 58 & 36 & 62 & 17 & 23 & 39 & 11 & Strong \\
\hline Malaysia & 86 & 82 & 84 & 88 & 59 & 61 & 66 & 30 & Weak \\
\hline Indonesia & 72 & 75 & 66 & 71 & 53 & 37 & 45 & 16 & Strong \\
\hline Afghanistan & 99 & 82 & 78 & 78 & 78 & 81 & 81 & 81 & Strong \\
\hline Bangladesh & 82 & 69 & 71 & 78 & 39 & 50 & 50 & 50 & Strong \\
\hline Pakistan & 84 & 54 & 84 & 87 & 68 & 85 & 88 & 69 & Strong \\
\hline Egypt & 74 & 75 & 94 & 95 & 91 & 70 & 70 & 70 & Strong \\
\hline Palestinian Terr. & 89 & 72 & 75 & 80 & 35 & 72 & 76 & 40 & Strong \\
\hline Tunisia & 56 & 58 & 42 & 62 & 17 & 28 & 44 & 8 & Strong \\
\hline Iraq & 91 & 57 & 73 & 76 & 43 & 55 & 56 & 45 & Strong \\
\hline Jordan & 71 & 80 & 93 & 93 & 93 & 54 & 57 & 47 & Weak \\
\hline Lebanon & 29 & 37 & 53 & 75 & 44 & 20 & 50 & 8 & Strong \\
\hline
\end{tabular}


Table 2: Average Support Levels for the Radical Agenda, Religious Judges, and Religious Leaders in Politics for Countries, Where Less than the Majority and More than the Majority of the Public Favored the Idea of Sharia as the Law of the Land

\begin{tabular}{|c|c|c|c|c|c|c|c|c|c|c|}
\hline & \multirow{2}{*}{$\begin{array}{c}\text { Public Support } \\
\text { Levels for } \\
\text { Sharia (\%) }\end{array}$} & \multicolumn{2}{|c|}{$\begin{array}{c}\text { Public Support Levels for } \\
\text { Corporal Punishment (\%) }\end{array}$} & \multicolumn{2}{|c|}{$\begin{array}{c}\text { Public Support Levels for } \\
\text { Religious Judges (\%) }\end{array}$} & \multicolumn{3}{|c|}{$\begin{array}{c}\text { Public Support Levels for } \\
\text { Religious Leaders in Politics (\%) }\end{array}$} \\
\cline { 3 - 11 } & $\begin{array}{c}\text { No to } \\
\text { Sharia }\end{array}$ & $\begin{array}{c}\text { Yes to } \\
\text { Sharia }\end{array}$ & Both & $\begin{array}{c}\text { No to } \\
\text { Sharia }\end{array}$ & $\begin{array}{c}\text { Yes to } \\
\text { Sharia }\end{array}$ & Both & $\begin{array}{c}\text { No to } \\
\text { Sharia }\end{array}$ & $\begin{array}{c}\text { Yes to } \\
\text { Sharia }\end{array}$ & Both \\
\hline $\begin{array}{c}\text { Less than } \\
\text { Majority }\end{array}$ & 22.4 & 11.1 & 39.1 & 16.3 & 16.3 & 53.3 & 22.9 & NA & NA & 30.4 \\
\hline $\begin{array}{c}\text { More than } \\
\text { Majority }\end{array}$ & 80.8 & 51.3 & 65.3 & 59.3 & 58 & 81.1 & 76.0 & NA & NA & 70.4 \\
\hline
\end{tabular}


Table 3: Summary of Linear Regression Analysis Parameters for the Combined Data

\begin{tabular}{|c|c|c|c|c|}
\hline Linear Regression Equations & $\mathrm{R}^{2}$ & $\mathrm{P}$-value & $\beta$ & $\delta \beta$ \\
\hline $\mathrm{B}=\beta \mathrm{A}+\alpha$ & 0.83 & $<0.001$ & 0.76 & 0.08 \\
\hline $\mathrm{C}=\beta \mathrm{A}+\alpha$ & 0.85 & $<0.001$ & 0.96 & 0.10 \\
\hline $\mathrm{A}=\beta \mathrm{C}+\alpha$ & 0.85 & $<0.001$ & 0.89 & 0.09 \\
\hline $\mathrm{B}=\beta \mathrm{C}+\alpha$ & 0.86 & $<0.001$ & 0.74 & 0.07 \\
\hline Mediation Equation: & 0.88 & $0.01^{*}$ & 0.32 & 0.18 \\
$\mathrm{~B}=\beta_{1} \mathrm{~A}+\beta_{2} \mathrm{C}+\alpha$ & & 0.02 & 0.42 & 0.17 \\
\hline $\begin{array}{c}\text { Moderation Equation }(\mathrm{A} * \mathrm{C} \text { is } \\
\text { the interaction term): }\end{array}$ & 0.91 & 0.02 & 0.40 & 0.16 \\
$\mathrm{~B}=\beta_{1} \mathrm{~A}+\beta_{2} \mathrm{C}+\beta_{3} \mathrm{~A}{ }^{*} \mathrm{C}+\alpha$ & & 0.03 & 0.84 & 0.35 \\
\hline
\end{tabular}

Table 4: Summary of Linear Regression Analysis Parameters for Those who Support Sharia

\begin{tabular}{|c|c|c|c|c|}
\hline Linear Regression Equations & $\mathrm{R}^{2}$ & $\mathrm{P}$-value & $\beta$ & $\delta \beta$ \\
\hline $\mathrm{B}=\beta \mathrm{A}+\alpha$ & 0.60 & $<0.001$ & 0.69 & 0.14 \\
\hline $\mathrm{B}=\beta_{1} \mathrm{~A}+\beta_{2} \mathrm{C}+\alpha$ & 0.72 & $0.02^{*}$ & 0.33 & 0.18 \\
& & 0.03 & 0.29 & 0.11 \\
\hline \multirow{3}{*}{$0 \beta_{1} \mathrm{~A}+\beta_{2} \mathrm{C}+\beta_{3} \mathrm{~A}^{*} \mathrm{C}+\alpha$} & 0.76 & 0.06 & 0.23 & 0.22 \\
& & 0.14 & 0.96 & 0.11 \\
\hline
\end{tabular}

Table 5: Summary of Linear Regression Analysis Parameters, No Support for Sharia

\begin{tabular}{|c|c|c|c|c|}
\hline Linear Regression Equations & $\mathrm{R}^{2}$ & $\mathrm{P}$-value & $\beta$ & $\delta \beta$ \\
\hline $\mathrm{B}=\beta \mathrm{A}+\alpha$ & 0.67 & $<0.001$ & 0.70 & 0.12 \\
\hline $\mathrm{B}=\beta_{1} \mathrm{~A}+\beta_{2} \mathrm{C}+\alpha$ & 0.75 & $0.045^{*}$ & 0.42 & 0.16 \\
& & 0.06 & 0.33 & 0.15 \\
$\mathrm{~B}=\beta_{1} \mathrm{~A}+\beta_{2} \mathrm{C}+\beta_{3} \mathrm{~A}^{*} \mathrm{C}+\alpha$ & 0.82 & 0.004 & 0.47 & 0.15 \\
& & 0.02 & 1.22 & 0.14 \\
\hline
\end{tabular}

$\beta$ : path coefficient (unstandardized); $\delta \beta$ : standard error; $\alpha$ : intercept; *: Sobel test P-values; A: the public support levels for religious leaders as religious judges; B: the public support levels for the radical agenda of cutting off the hands of thieves and robbers; $\mathrm{C}$ : the public support levels for Sharia as the law of the land 
Figure 1: Religious Leaders Versus the Radical Agenda Support Levels

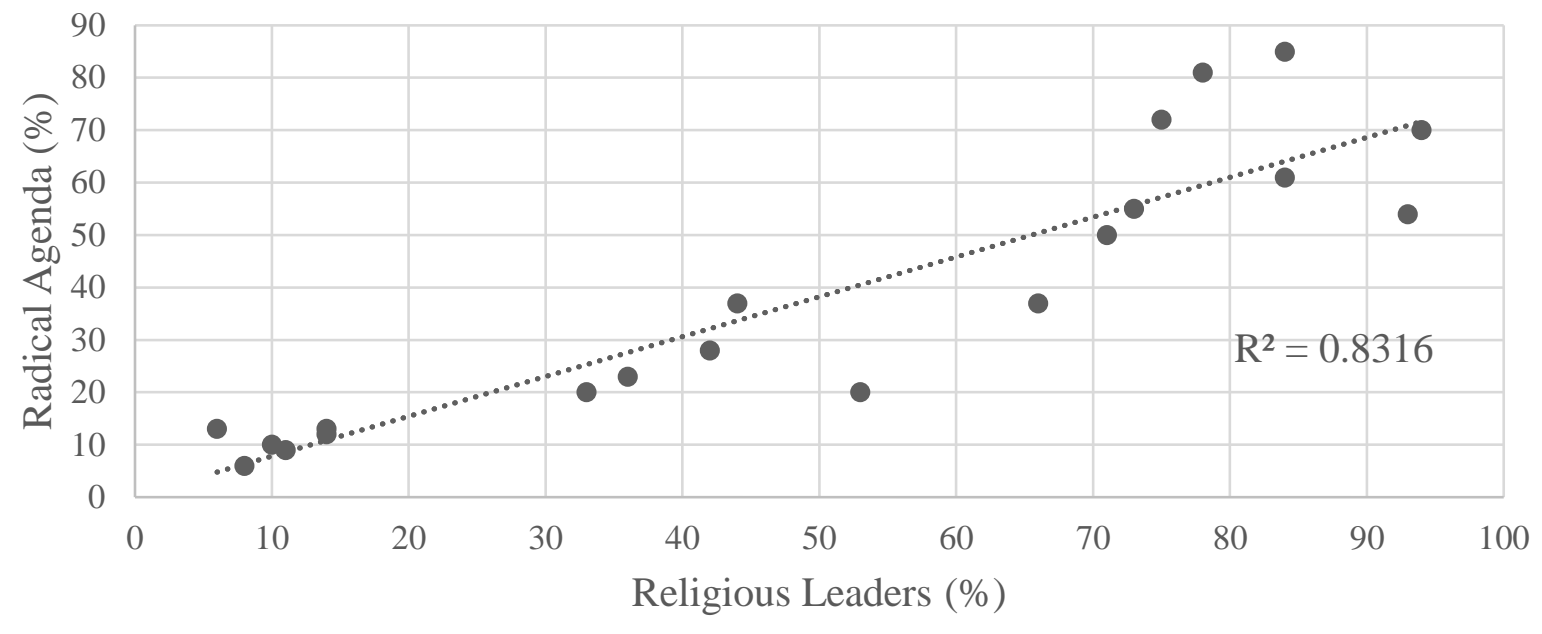

Figure 2: Sharia Versus Religious Leaders Support Levels

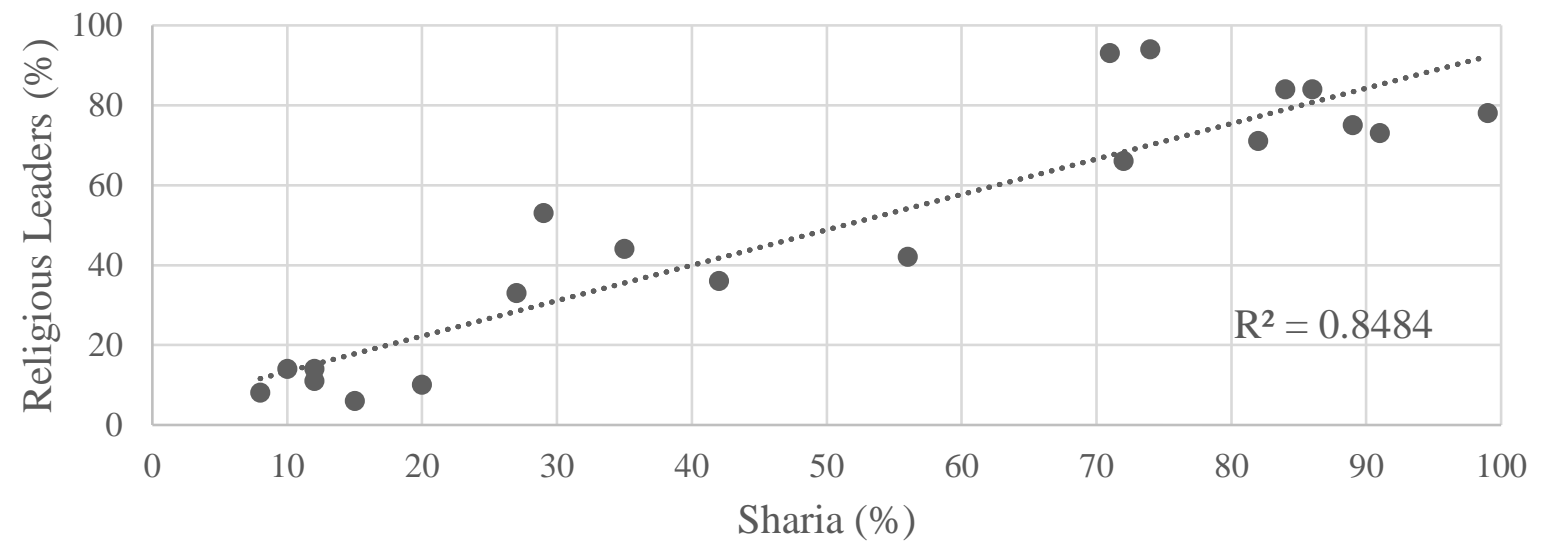

Figure 3: Sharia Versus the Radical Agenda Support Levels

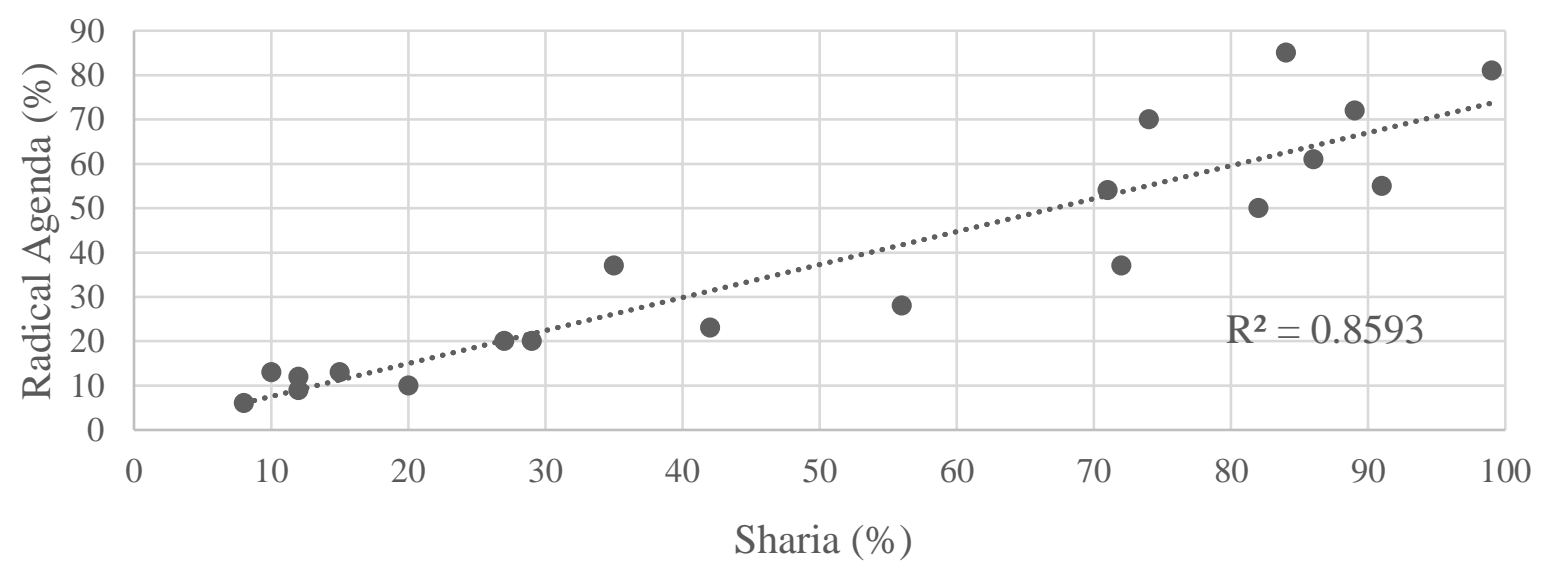

